\title{
A SOLID MEDIUM FOR CULTURE AND IDENTIFICATION OF HUMAN T-MYCOPLASMAS
}

\author{
G. D. Windsor, D. G. Ff. Edward AND Jacqueline A. Trigwell \\ Wellcome Research Laboratories, Beckenham, Kent and \\ The Public Health Laboratory, Dulwich Hospital, London
}

Plate X

T-MYCOPLASMAS produce very small colonies on solid media. This may be due to their
urease activity, leading to local accumulation of ammonia (Manchee and Taylor-Robinson,
1969); these authors increased the size of colonies by adding to the medium a new hydrogen-
ion buffer, N-2-hydroxy-ethylpiperazine-N-2-ethanesulphonic acid (HEPES). This observa-
tion suggested to us that other buffers might have a similar effect, and the present paper
describes the development of a solid medium containing phosphates for the growth and
identification of T-mycoplasmas. The latter have recently been placed in the new genus
Ureaplasma, the specific epithet for human isolates being urealyticum (Shepard et al., 1974).

\section{MATERIALS AND METHODS}

Organisms. All the mycoplasmas examined were human genital strains. T-mycoplasma, strain $T_{c}$, had been subcultured 11 times, and strains $T_{1}, T_{2}, T_{7}$ and $T_{10}$ only five times after isolation. Stock suspensions were stored, as broth cultures, at $-70^{\circ} \mathrm{C}$, in small amounts. Mycoplasma hominis, strain 164, was isolated at Dulwich Hospital and passaged three times on conventional mycoplasma medium before storage at $-70^{\circ} \mathrm{C}$.

Media. The basic medium used consisted of $1.2 \%$ Oxoid Agar, no. 3, in distilled water, $60 \mathrm{ml}$; horse serum (Wellcome no. 3), $20 \mathrm{ml} ; 25 \%$ extract of baker's yeast containing $18 \%$ Tryptone Soya Broth (Oxoid), $10 \mathrm{ml} ; 10 \%$ solution of urea (BDH Analar), $1 \mathrm{ml} ; 0.4 \%$ phenol red, $0.5 \mathrm{ml} ; 1 \%$ thallium acetate, $1 \mathrm{ml}$; and penicillin $(10,000$ units per $\mathrm{ml}), 2 \mathrm{ml}$. The $p \mathrm{H}$ was suitably adjusted, as described in the text, with $1.5 \mathrm{M}$-solutions of $\mathrm{KH}_{2} \mathrm{PO}_{4}$, $\mathrm{Na}_{2} \mathrm{HPO}_{4}, \mathrm{NaH}_{2} \mathrm{PO}_{4} .2 \mathrm{H}_{2} \mathrm{O}$ (all BDH Analar) or $\mathrm{K}_{2} \mathrm{HPO}_{4}$ (BDH Lab. reagent), or, in the case of non-buffered batches of media, with $1 \mathrm{~N}-$ or $0.1 \mathrm{~N}-\mathrm{HCl}(\mathrm{BDH}$ Analar) or $0.1 \mathrm{~N}-\mathrm{NaOH}$ (BDH Analar). The final volume of medium was made up to $100 \mathrm{ml}$ with distilled water. After inoculation, the plates were incubated at $36-37^{\circ} \mathrm{C}$ in an atmosphere of $95 \%$ nitrogen and $5 \% \mathrm{CO}_{2}$.

The fluid medium used for the original isolation of the T-mycoplasmas had the same composition as the solid medium but without agar and phosphate buffers, and the $p H$ was adjusted to 6.5 with $\mathrm{N}-\mathrm{HCl}$. Lincomycin, $12.5 \mu \mathrm{g}$ per ml, was added to suppress the growth of M. hominis (Braun et al., 1970).

Evaluation of colonial growth. Stock suspensions of T-mycoplasmas, suitably diluted to produce about 100 colonies per plate, were inoculated, in $0.05 \mathrm{ml}$ volumes, across the agar surface. Counts were done after 3-days' incubation, at 25-fold magnification for colonies on phosphate-buffered medium and 60-fold magnification for colonies on medium without buffer. Colony diameters were measured with a graticule and expressed as the average of ten colonies per plate.

Removal of soluble constituents from agar plates. The properties of the precipitate formed in T-mycoplasma colonies were examined after soluble medium components had been removed by washing. The agar gel was taken out of the petri dish, placed in a nylon net

Received 7 June 1974; accepted 22 June 1974. 
and immersed in approximately 1 litre of distilled water kept at $4^{\circ} \mathrm{C}$ and stirred magnetically. The water was changed after $2 \mathrm{~h}$, and the washing continued for a further $18 \mathrm{~h}$.

\section{Results}

Preliminary experiments had shown that the addition of a mixture of 7 parts of $1.5 \mathrm{M}$ $\mathrm{KH}_{2} \mathrm{PO}_{4}$ and 3 parts of $1.5 \mathrm{M} \mathrm{Na}_{2} \mathrm{HPO}_{4}$ to solid medium, producing a $p \mathrm{H}$ of 6.5 , increased the size of T-mycoplasma colonies. In the presence of urea, a white precipitate also appeared within the enlarged colonies and there was an alkaline shift in the $p \mathrm{H}$ of the medium, recognised by change in colour of the phenol red. Use of filter-sterilised instead of autoclaved tryptone soya broth and the addition of yeast extract caused a further slight increase in the size of colonies.

To investigate more fully the effect of phosphate buffer on the size of T-mycoplasma colonies, $7: 3$ part mixtures of $1.5 \mathrm{M}$-solutions of (1) $\mathrm{KH}_{2} \mathrm{PO}_{4}$ and $\mathrm{Na}_{2} \mathrm{HPO}_{4}$, (2) $\mathrm{KH}_{2} \mathrm{PO}_{4}$ and $\mathrm{K}_{2} \mathrm{HPO}_{4}$, (3) $\mathrm{NaH}_{2} \mathrm{PO}_{4} .2 \mathrm{H}_{2} \mathrm{O}$ and $\mathrm{Na}_{2} \mathrm{HPO}_{4}$ or (4) $\mathrm{NaH}_{2} \mathrm{PO}_{4} .2 \mathrm{H}_{2} \mathrm{O}$ and $\mathrm{K}_{2} \mathrm{HPO}_{4}$ were added to medium, in a range of concentrations from $0.25 \%$ to $7.5 \%$, and tested with strain $T_{c}$. With all four mixtures, maximum colony size was reached at $2.5 \%$ concentration, with no further increase at $5 \%$ and $7.5 \%$. Similar numbers of colonies were present throughout the concentration range but at $7.5 \%$ the colonies were largely obscured by precipitation throughout the medium. At $0.25 \%$ and $7.5 \%$ the colonies appeared translucent under the microscope but between $0.5 \%$ and $5.0 \%$ they were opaque because of a white precipitate within the colony. The colonies could be moved with a loop bodily across the surface of the agar.

Since significant differences were not found among the various phosphate mixtures the $\mathrm{KH}_{2} \mathrm{PO}_{4}-\mathrm{Na}_{2} \mathrm{HPO}_{4}$ combination, at a concentration of $2.5 \%$ in the medium, was selected for further study of $p \mathrm{H}$ effect. Batches of solid media were prepared containing $2.5 \%$ of various mixtures of $1.5 \mathrm{M} \mathrm{KH}_{2} \mathrm{PO}_{4}$ and $1.5 \mathrm{M} \mathrm{Na}_{2} \mathrm{HPO}_{4}$, to give a range of $p \mathrm{H}$, namely, 6.5 (7 parts $\mathrm{KH}_{2} \mathrm{PO}_{4}$ to 3 parts $\left.\mathrm{Na}_{2} \mathrm{HPO}_{4}\right), 7.0$ (4:6 parts), 7.5 (2:8 parts) and 8.0 (0.5: 9.5 parts). Similar batches of media without buffer were adjusted to the same range of $p \mathrm{H}$ with $0 \cdot 1 \mathrm{~N}-\mathrm{HCl}$ or $0.1 \mathrm{~N}-\mathrm{NaOH}$. Plates with and without phosphate buffer were then inoculated, in parallel, with strain $\mathrm{T}_{1}$ or $\mathrm{T}_{10}$. Neither the presence or absence of buffer nor the $p \mathrm{H}$ itself significantly affected the number of $T_{1}$ colonies that appeared but colony size decreased with increasing $p \mathrm{H}$ (table $\mathrm{I}$ ). In the case of $\mathrm{T}_{10}$, both number and size of colonies decreased with rise of $p \mathrm{H}$. However, with both $\mathrm{T}_{1}$ and $\mathrm{T}_{10}$, medium containing buffer at $p \mathrm{H} 6.5$ and $p \mathrm{H} \mathrm{7.0}$ produced larger colonies than did medium at the same $p \mathrm{H}$ but without buffer, and the colonies showed precipitate formation; neither enhancement of colony size nor precipitate was seen at $p \mathrm{H} \mathrm{7.5}$ and $p \mathrm{H} \mathrm{8.0.} \mathrm{Accordingly,} \mathrm{medium} \mathrm{containing} 2.5 \%$ of the $7: 3$-part mixture of $\mathrm{KH}_{2} \mathrm{PO}_{4}$ and $\mathrm{Na}_{2} \mathrm{HPO}_{4}, p \mathrm{H} 6 \cdot 5$, was chosen for further work.

A single batch of horse serum had been used for all the previous experiments. Table II shows the effect of four different batches of horse serum, which had been stored at $-20^{\circ} \mathrm{C}$, on colony size. Each serum was tested in solid medium with and without phosphate buffer (media without buffer were adjusted to $p \mathrm{H} 6.5$ with $0.1 \mathrm{~N}-\mathrm{HCl}$ ). In general, with all four sera, colonies of strains $T_{c}, T_{1}, T_{2}, T_{7}$ and $T_{10}$ were larger in the buffered medium; the only exceptions were the colonies of strains $T_{7}$ and $T_{10}$ on media containing horse serum batch no. 3. All colonies on buffered medium contained white precipitate and the colour of the medium changed from yellow to red.

Most of the precipitate that developed with T-mycoplasma colonies grown on buffered medium was removed by prolonged washing in distilled water. It was soluble in $33 \% \mathrm{HNO}_{3}$ (BDH Analar, sp. gr. 1.42), in 10\% trichloroacetic acid (BDH Lab. Reagent) and in 0.01 Methylenediamine tetra-acetate (EDTA) (BDH Analar). The presence of inorganic phosphate was detected by a modified vanadate-molybdate test (Michelsen, 1957), a positive yellow coloration being obtained with as few as two washed colonies; washed, uninoculated gel gave a negative test.

The low-passage strain, $M$. hominis no. 164, never produced a precipitate on buffered medium. This greatly facilitated the detection of small numbers of T-mycoplasmas, in freshly cultured specimens from patients, among numerous $M$. hominis colonies (figure). 


\section{TABLE I}

Effect of pH and phosphate buffer on the colonial growth of T-mycoplasmas

\begin{tabular}{|c|c|c|c|c|c|c|c|c|}
\hline \multirow{3}{*}{$\begin{array}{l}\text { Strain of } \\
\text { mycoplasma }\end{array}$} & \multicolumn{8}{|c|}{ Size $(\mu \mathrm{m})^{*}$ and number $\dagger$ (in parentheses) of colonies produced at } \\
\hline & \multicolumn{2}{|c|}{$p \mathrm{H} 6.5$} & \multicolumn{2}{|c|}{$p \mathrm{H} \mathrm{7.0}$} & \multicolumn{2}{|c|}{$\underbrace{p \mathrm{H} 7.5}$} & \multicolumn{2}{|c|}{$\underbrace{p \mathrm{H} 8.0}$} \\
\hline & $\begin{array}{l}\text { with } \\
\text { buffer }\end{array}$ & $\begin{array}{c}\text { without } \\
\text { buffer }\end{array}$ & $\begin{array}{l}\text { with } \\
\text { buffer }\end{array}$ & $\underset{\begin{array}{c}\text { without } \\
\text { buffer }\end{array}}{ }$ & $\begin{array}{c}\text { with } \\
\text { buffer }\end{array}$ & $\begin{array}{c}\text { without } \\
\text { buffer }\end{array}$ & $\begin{array}{l}\text { with } \\
\text { buffer }\end{array}$ & $\begin{array}{l}\text { without } \\
\text { buffer }\end{array}$ \\
\hline $\mathrm{T}_{1}$ & $168(212)$ & $67(210)$ & $115(216)$ & $56(274)$ & $58(226)$ & $53(213)$ & $53(225)$ & $43(208)$ \\
\hline$T_{10}$ & $199(21)$ & $48(20)$ & $137(31)$ & $39(13)$ & $59(6)$ & $42(6)$ & $50(2)$ & $33(4)$ \\
\hline
\end{tabular}

* Expressed as the average measurement of two sets of ten colonies on two plates. On plates with fewer than ten colonies, all colonies were measured.

$\dagger$ Mean plate count of duplicate cultures.

TABLE II

Effect of different batches of horse serum on the enhancing activity of phosphate-buffered medium for colony size of T-mycoplasmas

\begin{tabular}{|c|c|c|c|c|}
\hline \multirow[t]{2}{*}{$\begin{array}{c}\text { Strain of } \\
\text { T-mycoplasma }\end{array}$} & \multicolumn{4}{|c|}{$\begin{array}{l}\text { Proportionate increase in size of colonies grown on } \\
\text { phosphate-buffered medium, compared with unbuffered } \\
\text { medium, containing horse-serum batch number }\end{array}$} \\
\hline & 1 & 2 & 3 & 4 \\
\hline $\begin{array}{l}\mathbf{T}_{\mathbf{c}} \\
\mathbf{T}_{1} \\
\mathbf{T}_{2} \\
\mathbf{T}_{7} \\
\mathbf{T}_{10}\end{array}$ & $\begin{array}{l}3.9 \\
1.7 \\
2.9 \\
2.5 \\
\ldots\end{array}$ & $\begin{array}{l}2.3 \\
1.8 \\
\dddot{2.2} \\
2.7\end{array}$ & $\begin{array}{l}\dddot{1.8} \\
1.6 \\
1.0 \\
0.8\end{array}$ & $\begin{array}{c}3.5 \\
1.3 \\
\dddot{2.4} \\
2.0\end{array}$ \\
\hline
\end{tabular}




\section{Discussion}

A differential agar medium, containing urea and $\mathrm{MnSO}_{4}$, was described by Shepard and Lunceford (1970) for the identification of T-mycoplasmas. Specific urease activity produced a white reaction product in the colonies (Shepard,1973). We obtained colonies with a similar internal precipitate on the phosphate-buffered medium, and treatment of the colonies with $1 \%$ urea solution containing $0.8 \% \mathrm{MnCl}_{2}$ (Shepard, 1973) produced no change in their appearance. This suggests that the specific urease activity of T-mycoplasmas can be demonstrated in a urea-containing medium, buffered with phosphate to increase colonial size, without the further addition of a heavy metal salt.

The precipitate was found to contain phosphate, and its solubility in EDTA suggests that the phosphate is combined with an alkaline earth, which is probably calcium because this is the predominant alkaline earth in serum. Its formation can be accounted for by the production of ammonium ions, by the urease activity of the T-mycoplasmas, which then combine with calcium and phosphate ions to give insoluble calcium ammonium phosphate. At high concentrations of phosphate buffer $(7.5 \%)$, ammonium ions would combine solely with the phosphate ions to form soluble ammonium phosphate. The production of magnesium ammonium phosphate by T-mycoplasmas has recently been reported in rats (Friedlander and Braude, 1974).

Thallium acetate, $0.01 \%$, was incorporated routinely in the medium, although it has been the practice of Shepard (1969) never to use this inhibitor of bacteria. However, Edward (1947) noted that it had some inhibitory activity against classical mycoplasmas, and recommended the incorporation of $0.0125 \%$ in solid media. Concentrations as high as $0.02 \%$ have been found to have little effect on the isolation rate of T-mycoplasmas (Lee, Bailey and McCormack, 1972).

Although we have found that T-mycoplasmas freshly isolated in liquid media tend to produce smaller colonies on the phosphate-buffered solid medium than do laboratory stock cultures, all of them produce colonies with precipitate, visible usually within $48 \mathrm{~h}$ at 25 -fold magnification. and colour change in the medium. Although the experimental work has been confined to human isolates, the same medium is probably also suitable for the isolation and identification of animal T-mycoplasmas.

\section{SUMMARY}

A solid, urea-containing medium buffered to $p \mathrm{H} 6.5$ with a suitable mixture of $\mathrm{KH}_{2} \mathrm{PO}_{4}$ and $\mathrm{Na}_{2} \mathrm{HPO}_{4}$ produced enlarged $\mathrm{T}$-mycoplasma colonies containing a white precipitate. This was absent from $M$. hominis colonies. The medium can be used for the isolation and identification of T-mycoplasmas.

We would like to thank Mr A. E. Pink for assistance with the analyses and Mr E. J. Kentish for the photography.

\section{REFERENCES}

Braun, P., Klein, J. D., Lee, Y. H. AND Kass, E. H. 1970. Methodologic investigations and prevalence of genital mycoplasmas in pregnancy. J. infect. Dis., 121, 391.

EDWARD, D. G. FF. 1947. A selective medium for pleuropneumonia-like organisms. J. gen. Microbiol., 1, 238.

Friedlander, A. M. ANd Braude, A. I. 1974. Production of bladder stones by human T-mycoplasmas. Nature, Lond., 247, 67.

LeE, Y. H., BAiley, P. E. AND McCoRmaCK, W. M. 1972. T-mycoplasmas from urine and vaginal specimens: decreased rates of isolation and growth in the presence of thallium acetate. J. infect. Dis., 125, 318.

MANCheE, R. J. AND TAYLOR-Robinson, D. 1969. Enhanced growth of T-strain mycoplasmas with $\mathrm{N}$-2-hydroxethyl-piperazine-N-2-ethanesulfonic acid buffer. J. Bact., $100,78$. 


\section{SOLID MEDIUM FOR T-MYCOPLASMAS}

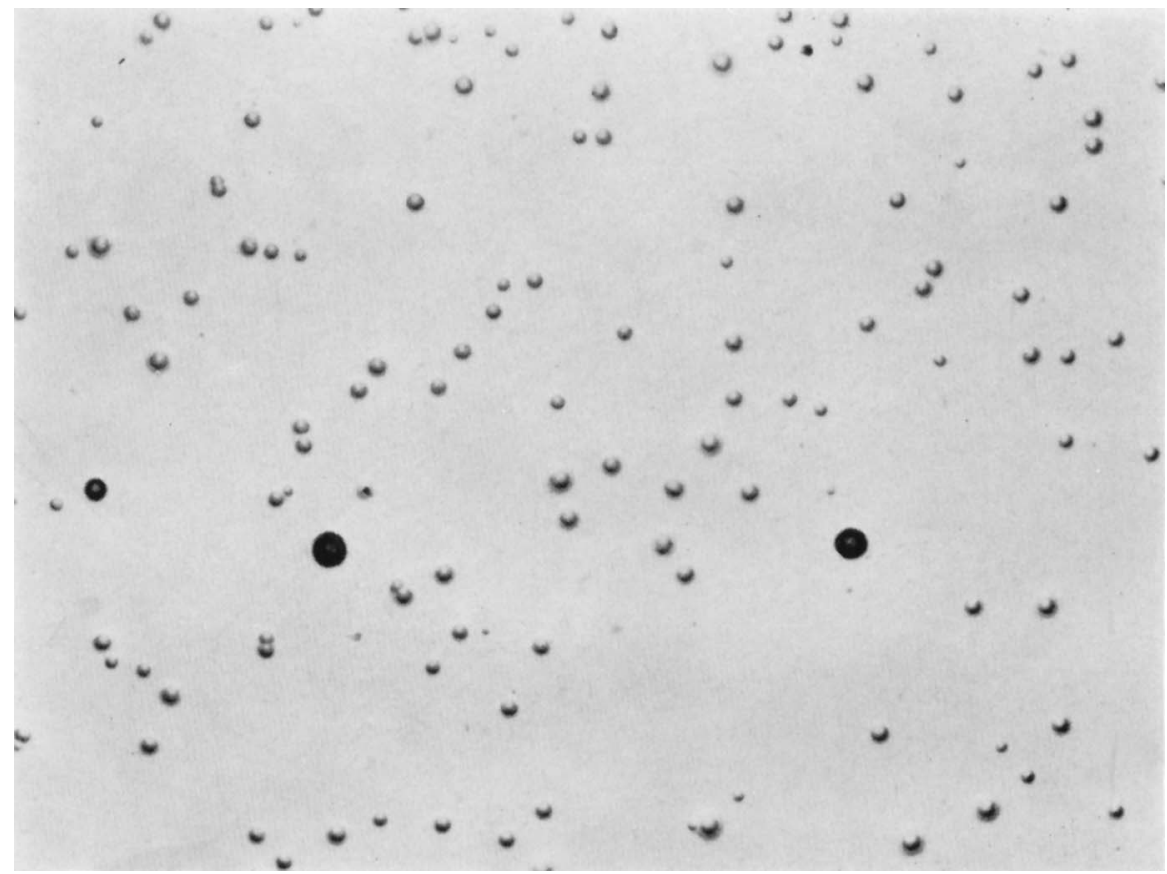

FIGURE-Subculture on to phosphate-buffered solid medium from a cervical swab culture in liquid medium. After 48 hours' incubation, three T-mycoplasma colonies (dark) are visible among numerous $M$. hominis colonies. $\times 40$. 
Michelsen, O. B. 1957. Photometric determination of phosphorus as molybdovanadophosphoric acid. Analyt. Chem., 29, 60.

ShePARD, M. C. 1969. Fundamental biology of the T-strains. In The Mycoplasmatales and the L-phase of bacteria, edited by L. Hayflick, New York, p. 49.

SHEPARD, M. C. 1973. Differential methods for identification of T-mycoplasmas based on demonstration of urease. J. infect. Dis., 127, Suppl. S22.

SHEPARD, M. C. AND LunCEFoRd, C. D. 1970. Differential agar medium for identification of T-mycoplasmas in primary cultures. Bact. Proc., p. 83.

Shepard, M. C., Lunceford, C. D., Ford, D. K., Purcell, R. H., Taylor-Robinson, D., RAZIN, S. AND BlACK, F. T. 1974. Ureaplasma urealyticum gen. nov., sp. nov: proposed nomenclature for the human $\mathrm{T}$ (T-strain) mycoplasmas. Int. J. syst. Bact., 24, 160. 